\title{
TAXATION AND UNEMPLOYMENT: AN APPLIED GENERAL EQUILIBRIUM APPROACH
}

\author{
CHRISTOPH BOEHRINGER \\ STEFAN BOETERS \\ MICHAEL FEIL
}

CESIFO WORKING PAPER NO. 1272

CATEGORY 4: LABOUR MARKETS

SEPTEMBER 2004

Presented at Venice Summer Institute, WORKSHOP ON POLICY ANALYSIS WITH NUMERICAL MODELS, JULY 2004

\footnotetext{
An electronic version of the paper may be downloaded

- from the SSRN website: http://SSRN.com/abstract $=601581$

- from the CESifo website: www.CESifo.de
} 


\title{
TAXATION AND UNEMPLOYMENT: AN APPLIED GENERAL EQUILIBRIUM APPROACH
}

\begin{abstract}
We present an applied general equilibrium modelling approach to analyse employment and unemployment effects of labour tax cuts in an economy where wages are determined through firm-union bargaining at the sectoral level. In such a labour market regime, simulations for Germany show that labour tax policies can make only a small contribution to alleviating the problem of persistent unemployment.

JEL classification: D58, E62, J60.
\end{abstract}

Keywords: applied general equilibrium, wage bargaining, labour tax policy.

\author{
Christoph Boehringer \\ University of Heidelberg \\ Department of Economics \\ Grabengasse 14 \\ 69117 Heidelberg \\ Germany
}

\author{
Stefan Boeters \\ Centre for European Economic Research \\ PO Box 103443 \\ 68034 Mannheim \\ Germany \\ boeters@zew.de
}

\author{
Michael Feil \\ Institute for Employment Research (IAB) \\ Regensburger Straße 104 \\ 90478 Nürnberg \\ Germany \\ Michael.Feil@iab.de
}

We are grateful to a referee of the jounal of the CEER Mannheim for a number of clarifying suggestions. 


\section{Introduction}

Persistent unemployment at high levels is a central policy problem in many European countries (see OECD 2001 for a recent overview). Among the alternative policy proposals to reduce unemployment, tax policy shifts have received much interest. If it should turn out that tax cuts on labour can produce major positive labour market effects, this would give politicians a much less controversial instrument than radical changes in the institutional labour market settings.

During the last decade, the effects of taxation on unemployment have been a major research topic in public finance (see Sørensen 1997 for an overview). The respective literature combines different theories of equilibrium unemployment with classical methods of tax incidence analysis. Although rigorous analytical models provide a number of important insights, e.g. the positive impact of labour income tax progression on employment (Hoel 1990, Lockwood and Manning 1993, Koskela and Vilmunen 1996, Goerke 1997), their contribution to practical policy making remains rather limited. The reason is that theoretical models used to investigate the relationship between taxation and (un-)employment are highly stylised in order to keep analytical tractability. Accounting for a more detailed production or consumption structure and the specific institutional features of a country's labour market or tax system makes analytical solutions unavailable, thus requiring numerical solution methods. For a quantitative assessment of the labour market impacts induced by realistic tax policy shifts, the step from stylised analytical to complex numerical models is inevitable. Such a transition has occurred since the early 1980s in the fields of applied tax and trade policy analysis using computable general equilibrium models in particular (see e.g. Shoven and Whalley 1984, Ballard et al. 1985). The general equilibrium approach provides a comprehensive framework for studying the effects of policy interference on all markets of an economy, based rigorously on microeconomic theory. The simultaneous explanation of income generation and spending for all economic agents allows us to address both efficiency as well as distributional effects of policy changes. This is why applied general equilibrium (AGE) models have become a standard tool for quantitative policy analysis (for surveys on the use of AGE models in different policy fields see e.g. Shoven and Whalley 1992, Pereira 
and Shoven 1992, Kehoe and Kehoe 1994, Fehr and Wiegard 1996, or Weyant 1999).

To date, however, little work has been done to incorporate unemployment features within the applied general equilibrium framework, even though labour market effects of policy interference have become a key interest to decision-makers. A common ad hoc modelling approach is to replace the competitive labour market of a standard general equilibrium setting with a "wage curve" (Blanchflower and Oswald 1994). The wage curve reflects empirical evidence on the inverse relationship between the level of wages and the rate of unemployment. In such a model, the wage curve, together with labour demand, determines the level of involuntary unemployment (see e.g. Böhringer et al. (2003)). The wage curve constitutes a convenient shortcut to incorporate unemployment, but it lacks an explicit micro-foundation. This makes it impossible to analyse how specific policy measures affect the wage setting mechanism.

In order to track down the causal chain from policy interference to labour market effects one must open the "black box" of the wage curve and explicitly model the wage-setting process. Concrete examples include the efficiency-wage model provided by Hutton and Ruocco (1999) for selected EU countries and MIMIC, a detailed model of the Dutch labour market (Bovenberg et al. 2000, Graafland et al. 2001), in which wages are determined by centralised collective bargaining between firms and trade unions. In the MIMIC model, the wage bargaining equation contains economywide averages of the bargaining power, output and labour demand elasticities and, therefore, largely neglects sector-specific characteristics.

Here, we present an AGE modelling approach to incorporate sectoral wage bargaining which is relevant for various OECD countries including Germany, Spain, or Sweden (see EIRO, 2002): Wages are determined through firm-union bargaining at the sectoral level. Different economic conditions across sectors then produce different bargaining settings with varying bargaining power for firms and unions, making wage negotiations sensitive to the specific conditions in each sector.

From a methodological point of view our model feature of sectoral heterogeneity in wage bargaining provides an innovative contribution to the AGE literature. From the viewpoint of policy analysis, illustrative simulations for Germany indicate that cuts in labour taxes can make only a small contribution to alleviating the problem 
of persistent unemployment. Given the rather small impacts of tax policy changes, the ranking of the different tax instruments in terms of output and employment is rather robust and can mainly traced back to changes in the progressivity of the wage income tax system. However, the welfare consequences for workers and capitalists can differ substantially with varying assumptions on capital mobility.

The remainder of the paper is organized as follows: Section 2 describes the algebraic model structure and lays out in detail how sectoral wage bargaining can be incorporated into the general equilibrium framework. Section 3 provides illustrative simulations of labour tax policies for Germany. Section 4 concludes the paper.

\section{Model Description}

We present a detailed algebraic description of a static multi-sector general equilibrium model for an open economy. The innovative feature of our model is the incorporation of decentralised wage bargaining. In each sector, an employers' organisation and a labour union are engaged in wage negotiations, which are modelled as a "right-to-manage" Nash-bargaining. We assume that the bargaining parties have rational expectations about the labour demand outcome. For each sector, an individual wage equation with specific bargaining parameters is set up and calibrated, taking into account empirical wage differentials between sectors. Workers are classified into two skill types. They are mobile, but they can only change sectors during a period of unemployment. Matching of unemployed workers with vacant jobs is random.

\subsection{Firms}

\subsubsection{Production}

In each production sector, a representative firm produces a homogenous output. We use a nested constant-elasticity-of-substitution (CES) production function to reflect 


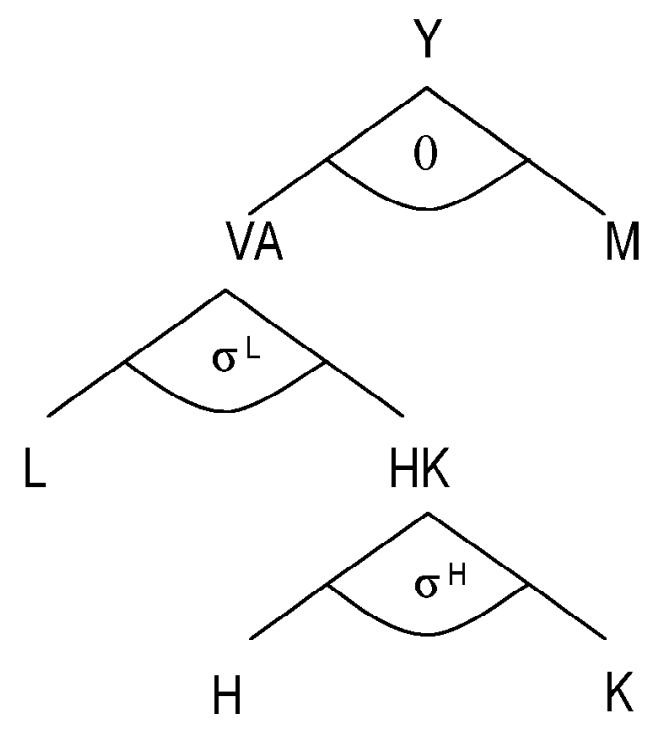

Figure 1: Nesting structure of production function

empirical evidence on the substitution possibilities. Figure 1 provides a diagrammatic overview of the nesting structure.

In the top nest, a material composite $(M)$ is combined in fixed proportions with aggregate value added (VA). $M$ consists of intermediate inputs with fixed coefficients (Leontief production structure), whereas $V A$ consists of low-skilled labour $(L)$ and a composite of high-skilled labour $(H)$ and capital $(K)$, trading off at a constant elasticity of substitution. The nesting reflects empirical evidence that $L$ is a relatively good substitute for both $H$ and $K$, whereas $H$ and $K$ are relatively bad substitutes for each other. Adopting the calibrated share form (see Appendix I), the cost function for each sector $s$ can be written as

$$
c_{s}=\beta_{s}^{V A} c_{v a, s}+\left(1-\beta_{s}^{V A}\right) c_{m, s}
$$

with

$$
\begin{gathered}
c_{v a, s}=\left[\beta_{s}^{L}\left(\frac{w_{L, s}\left(1+t_{l, L}\right)}{\bar{w}_{L, s}\left(1+\bar{t}_{l, L}\right)}\right)^{1-\sigma_{s}^{L}}+\left(1-\beta_{s}^{L}\right) c_{h k, s}^{1-\sigma_{s}^{L}}\right]^{\frac{1}{1-\sigma_{s}^{L}}} \\
c_{h k, s}=\left[\beta_{s}^{H}\left(\frac{w_{H, s}\left(1+t_{l, H}\right)}{\bar{w}_{H, s}\left(1+\bar{t}_{l, H}\right)}\right)^{1-\sigma_{s}^{H}}+\left(1-\beta_{s}^{H}\right)\left(\frac{r\left(1+t_{k}\right)}{\bar{r}\left(1+\bar{t}_{k}\right)}\right)^{1-\sigma_{s}^{H}}\right]^{\frac{1}{1-\sigma_{s}^{H}}},
\end{gathered}
$$




$$
c_{m, s}=\sum_{s s} \frac{p_{a, s s}}{\chi_{s s}}
$$

where

$c_{j, s}:=$ cost index of intermediary aggregate $j$,

$\beta_{s}^{V A}:=$ benchmark value share of $V A$ in total cost,

$\beta_{s}^{L} \quad:=$ benchmark value share of $L$ in $V A$ aggregate,

$\beta_{s}^{H}:=$ benchmark value share of $H$ in $H K$ aggregate,

$w_{i, s}:=$ wage of skill group $i$ (gross of wage tax),

$r \quad:=$ rental rate of capital,

$p_{a, s s}:=$ price of Armington good $s s$,

$\chi_{s s}:=$ fixed quantity of Armington good $s s$,

$\sigma_{s}^{L} \quad:=$ elasticity of substitution in $V A$ nest,

$\sigma_{s}^{H} \quad:=$ elasticity of substitution in $H K$ nest,

$t_{l, i}:=$ social security contributions of labour of type $i$,

$t_{k, s}:=$ capital input tax,

and the "bar" superscript denotes benchmark values.

Each individual firm is assumed to be small in relation to its respective sector. All firms in one sector interact through monopolistic competition, i.e. they produce individual variants of the sectoral output good, which attract different consumers. This means that firms can exploit market power in their respective market segment. Producer output prices then consist of costs (of the three primary inputs as well as intermediary inputs) plus a fixed mark-up. The budget constraint of the representative firm reads

$$
\left(1-m_{s}\right) p_{y, s} Y_{s}=\sum_{s s} p_{a, s s} A_{s s, s}+r\left(1+t_{k}\right) K_{s}+\sum_{i} w_{i, s}\left(1+t_{l, i}\right) L_{i, s}
$$

where

$$
\begin{aligned}
& m_{s}:=\text { price mark-up rate } \\
& p_{y, s}:=\text { output price, } \\
& Y_{s}:=\text { output quantity, } \\
& A_{s s, s}:=\text { intermediary input from Armington good } s s \\
& K_{s}:=\text { capital input, } \\
& L_{i, s}:=\text { labour input of skill type } i .
\end{aligned}
$$


Profits in sector $s$ are given by

$$
\pi_{s}=m_{s} p_{y, s} Y_{s}
$$

\subsubsection{Factor Demand}

Cost minimisation yields the following demand functions for the primary factors at the sectoral level:

$$
\begin{aligned}
K_{s} & =Y_{s}\left(\frac{c_{v a, s}}{c_{h k, s}}\right)^{\sigma_{s}^{L}}\left(c_{h k, s} \frac{\bar{r}\left(1+\bar{t}_{k}\right)}{r\left(1+t_{k}\right)}\right)^{\sigma_{s}^{H}}, \\
L_{H, s} & =Y_{s}\left(\frac{c_{v a, s}}{c_{h k, s}}\right)^{\sigma_{s}^{L}}\left(c_{h k, s} \frac{\bar{w}_{H, s}\left(1+\bar{t}_{l, H}\right)}{w_{H, s}\left(1+t_{l, H}\right)}\right)^{\sigma_{s}^{H}}, \\
L_{L, s} & =Y_{s}\left(c_{v a, s} \frac{\bar{w}_{L, s}\left(1+\bar{t}_{l, L}\right)}{w_{L, s}\left(1+t_{l, L}\right)}\right)^{\sigma_{s}^{L}} .
\end{aligned}
$$

The implied uncompensated (own and cross) price elasticities for labour are

$$
\begin{aligned}
\eta_{H H, s} & =-\beta_{s}^{H} \beta_{s}^{L} \sigma_{s}^{L}-\left(1-\beta_{s}^{H}\right) \sigma_{s}^{H}-\theta_{s}^{H} / m_{s}, \\
\eta_{H L, s} & =\beta_{s}^{L} \sigma_{s}^{L}-\theta_{s}^{L} / m_{s}, \\
\eta_{L H, s} & =\left(1-\beta_{s}^{L}\right) \beta_{s}^{H} \sigma_{s}^{L}-\theta_{s}^{H} / m_{s}, \\
\eta_{L L, s} & =-\left(1-\beta_{s}^{L}\right) \sigma_{s}^{L}-\theta_{s}^{L} / m_{s},
\end{aligned}
$$

where

$\theta_{s}^{i}:=$ value share of labour skill type $i$ in total production costs,

$m_{s}:=$ price mark-up (reciprocal of the output demand elasticity).

Note that the terms on the RHS containing the $\sigma$ 's are the compensated labour demand elasticities; the last term in each expression accounts for the output variation. (For the relation between compensated and uncompensated elasticities, see e.g. Hamermesh 1993, pp. 22-38.)

Capital and labour are mobile across sectors (see Section 2.3.2 for the representation of intersectoral labour mobility in the presence of cross-sector wage differentials). The market for capital is perfectly competitive. In our central model variant, we assume that capital is internationally immobile, which reflects a shortto medium-run model horizon. Sensitivity analysis of policy intervention with respect to international capital mobility will be performed in Section 3.2. 


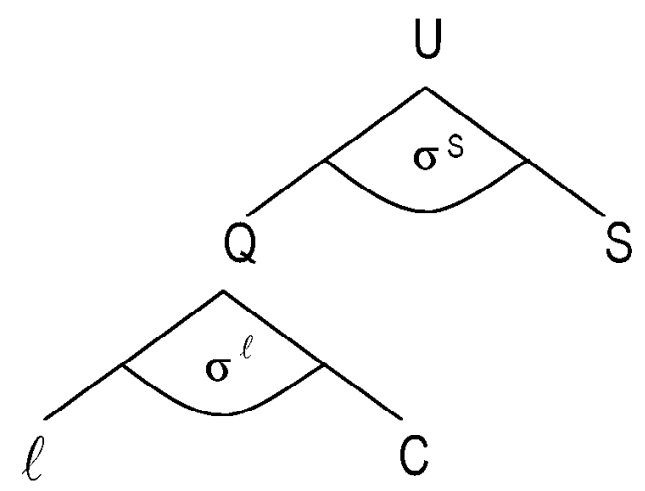

Figure 2: Utility nesting of representative worker

\subsection{Private Households}

The household sector is differentiated into three representative households, two worker households and one capitalist household. For both skill groups, there is one worker household that receives both labour income and unemployment benefits. The latter is proportional to the time spent unemployed with the replacement rate fixed at a constant fraction of the net wage. The worker households may also receive a fraction of the capital $\left(\kappa_{i}\right)$ and profit income $\left(\gamma_{i}\right)$. The third household is only endowed with capital and property rights of the firms. If $\kappa_{i}=\gamma_{i}=0$ (which is our default setting), the functional distribution of incomes is clear-cut. If the worker households receive part of the capital and profit incomes, we assume that it is distributed between them in proportion to their empirical benchmark savings. In addition to the factor incomes, there is either a lump-sum tax or a transfer to balance the government's budget (see Section 2.4).

The CES utility function of workers is illustrated in Figure 2.

At the top level, households decide over current versus future consumption, i.e. $S$. "Current utility" $Q$ is an aggregate of leisure $(l)$ and the consumption good composite $(C)$. The capitalist household does not supply labour, so "current utility" is confined to the consumption good composite. 


\subsubsection{Savings and Investment}

The representation of the savings decision follows the approach of Ballard et al. (1985). They derive a savings function in which savings are sensitive to both the real interest rate and the price of investment goods. The households' savings then correspond to the purchase of a uniform investment good at price $P_{I}$ per unit. This investment good is a fixed-coefficient composite of all Armington goods (see Section 2.5). Households derive their utility from the future stream of consumption that corresponds to the return to investment. In formal terms, the households' trade-off between current and future consumption on the top level of their decision problem is

$$
\max U_{i}\left(Q_{i}, C_{i}^{F}\right) \quad \text { s.t. } \quad P_{Q, i} H_{i}+P_{S} C_{i}^{F}=I_{e, i}
$$

where

$Q_{i}:=$ current utility aggregate,

$C_{i}^{F}:=$ stream of future consumption,

$P_{Q, i}:=$ price of $Q_{i}$,

$P_{S} \quad:=$ price of $C_{i}^{F}$,

$I_{e, i}:=$ extended income, see (16).

The crucial point in the savings calculus is the determination of $P_{S}$, which is the key determinant of savings demand. Each unit of investment (savings), $S$, generates a stream of $\phi$ units of capital services in each future period (where $\phi$ is a constant determined by the steady state condition). These services yield yearly income at rate $r$ (net of taxes), which is then traded for the consumption goods composite at rate $P_{C}$ (note that $P_{C}$ is not differentiated across households, because all households are assumed to have the same consumption spending pattern). For static expectations, i.e. households expect all prices to remain at their current levels, savings will yield the following consumption possibilities:

$$
C^{F}=\frac{\phi r}{P_{C}}
$$

Together with the price $P_{I}$ of the investment good, which is defined as Leontief aggregate over Armington goods, we then obtain

$$
P_{S}=\frac{P_{I} P_{C}}{\phi r}
$$


In calibrated share form, $U$ reads as

$$
U_{i}=\left[\theta_{i}^{Q}\left(\frac{Q_{i}}{\bar{Q}_{i}}\right)^{\frac{1-\sigma_{i}^{s}}{\sigma_{i}^{s}}}+\left(1-\theta_{i}^{Q}\right)\left(\frac{S_{i}}{\bar{S}_{i}}\right)^{\frac{1-\sigma_{i}^{s}}{\sigma_{i}^{s}}}\right]^{\frac{\sigma_{i}^{s}}{1-\sigma_{i}^{s}}}
$$

with $\theta_{i}^{Q}$ denoting the value share of current consumption in extended income. The associated unit expenditure function is

$$
P_{U, i}=\left[\theta_{i}^{Q}\left(\frac{P_{Q, i}}{\bar{P}_{Q, i}}\right)^{1-\sigma_{i}^{s}}+\left(1-\theta_{i}^{Q}\right)\left(\frac{P_{S}}{\bar{P}_{S}}\right)^{1-\sigma_{i}^{s}}\right]^{\frac{1}{1-\sigma_{i}^{s}}} .
$$

This yields the following savings demand function:

$$
S_{i}=\bar{S}_{i}\left(\frac{P_{U, i} \bar{P}_{S}}{\bar{P}_{U, i} P_{S}}\right)^{\sigma_{i}^{s}} \frac{I_{e, i} \bar{P}_{U, i}}{\bar{I}_{e, i} P_{U, i}} .
$$

It is important to note that the assumption of a flexible savings price drives a wedge between the amount of money actually spent on investment goods and the savings term appearing in the utility maximising problem, because $P_{S}$ generally does not equal $P_{I}$. In order to assure that the households' budget constraints actually hold (i.e. outlays equal income), we must correct for the difference between $P_{S}$ and $P_{I}$. Extended income $I_{e, i}$ then becomes

$$
I_{e, i}=\sum_{s} \tilde{w}_{i, s} L_{i, s}+b_{i} L_{U, i}+r V_{U, i} l_{i}+\kappa_{i} r \bar{K}+\gamma_{i} \Pi+\left(P_{S}-P_{I}\right) S_{i}-T_{L S, i}
$$

where

$$
\begin{array}{ll}
\tilde{w}_{i, s}:=\text { net wage rate } \\
b_{i}:=\text { unemployment benefit, } \\
r V_{U, i}:=\text { value of unemployed time, } \\
\bar{K} & :=\text { aggregated capital stock, } \\
\Pi & :=\text { aggregated profits, } \\
T_{L S, i} & :=\text { lump-sum tax or benefit (see Section } 2.4) .
\end{array}
$$

Equation (16) forms the basis for the benchmark value shares $\theta_{i}^{Q}$. The savings decision of the capitalist household is derived analogously. 


\subsubsection{Labour Supply}

On the second level of the utility maximisation problem, households decide about leisure and current consumption. Time endowment is divided into three components: leisure, labour time, and time spent unemployed (searching for a job). Labour time per skill type $L_{i}$ (in value units) is given as

$$
L_{i}=\sum_{s} L_{i, s}
$$

where

$$
L_{i, s}:=\text { labour demand by sector. }
$$

Unemployed time in the benchmark is calculated as

$$
L_{U, i}=u_{i} L_{i} /\left(1-u_{i}\right),
$$

where

$$
\begin{aligned}
u_{i}:= & \text { benchmark unemployment } \\
& \text { (as a fraction of total labour supply } \left.L_{S, i}=L_{i}+L_{U, i}\right) .
\end{aligned}
$$

Leisure $\left(l_{i}\right)$, as the third component of total time endowment, is calculated as

$$
l_{i}=(\zeta-1) L_{S, i}
$$

where

$$
\zeta:=\text { ratio of total time endowment to labour supplied. }
$$

Thus, total labour endowment $\bar{L}_{i}$ can be written as

$$
\bar{L}_{i}=L_{i}+L_{U, i}+l_{i}
$$

A key assumption about the households' labour supply behaviour in our modelling approach is that workers cannot directly enter employment. Each additional unit of labour is first unemployed for a certain period and may then be combined with a job according to a stochastic matching process (see Section 2.3.2). Consequently, the marginal decision of each household depends only on the annualised value of 
unemployed time, $r V_{U, i}$. However, the inframarginal units of labour receive the net of tax wage $\tilde{w}_{i, s}$ when employed in sector $s$, or $b_{i}$ when unemployed ( $b_{i}$ can be chosen to be either fixed in absolute terms or as a fraction of the net wage). The net wage is derived from the gross wage by imposing a linear progressive wage tax:

$$
\tilde{w}_{i, s}=w_{i, s}-t_{w m, i}\left(w_{i, s}-A_{i}\right)
$$

where:

$t_{w m, i}:=$ marginal tax rate,

$A_{i} \quad:=$ allowable tax deduction.

The average tax rate is denoted by $t_{w, i}$ and can be calculated as

$$
t_{w, i}=1-\frac{\tilde{w}_{i, s}}{w_{i, s}}=t_{w m, i}\left(1-\frac{A_{i}}{w_{i, s}}\right) .
$$

The CES subutility function on the second level is

$$
\frac{Q_{i}}{\bar{Q}_{i}}=\left[\theta_{i}^{C}\left(\frac{C_{i}}{\bar{C}_{i}}\right)^{\frac{1-\sigma_{i}^{l}}{\sigma_{i}^{l}}}+\left(1-\theta_{i}^{C}\right)\left(\frac{l_{i}}{\bar{l}_{i}}\right)^{\frac{1-\sigma_{i}^{l}}{\sigma_{i}^{l}}}+\right]^{\frac{\sigma_{i}^{l}}{1-\sigma_{i}^{l}}}
$$

with corresponding expenditure and demand functions:

$$
\begin{aligned}
\frac{P_{Q, i}}{\bar{P}_{Q, i}} & =\left[\theta_{i}^{C}\left(\frac{P_{C}}{\bar{P}_{C}}\right)^{1-\sigma_{i}^{l}}+\left(1-\theta_{i}^{C}\right)\left(\frac{r V_{U, i}}{\bar{r} \bar{V}_{U, i}}\right)^{1-\sigma_{i}^{l}}+\right]^{\frac{1}{1-\sigma_{i}^{l}}}, \\
l_{i} & =\frac{Q_{i}}{\overline{\bar{Q}}_{i}}\left(\frac{P_{Q, i}}{\bar{P}_{Q, i}} \frac{\bar{r} \bar{V}_{U, i}}{r V_{U, i}}\right)^{\sigma_{i}^{l}}, \\
\frac{C_{i}}{\bar{C}_{i}} & =\frac{Q_{i}}{\bar{Q}_{i}}\left(\frac{P_{Q, i}}{\bar{P}_{Q, i}} \frac{\bar{P}_{C}}{P_{C}}\right)^{\sigma_{i}^{l}},
\end{aligned}
$$

where:

$\theta_{i}^{C}:=$ benchmark value share of consumption in the value of current utility.

\subsubsection{Consumption}

Aggregate consumption for each of the two representative worker households is determined together with labour supply. As we assume identical consumption spending patterns for all three households, aggregate consumption across households is 


$$
C=\sum_{i} C_{i}+C_{K}
$$

where

$C \quad:=$ aggregate consumption/supply of aggregate consumption good,

$C_{i}:=$ consumption of worker household $i$,

$C_{K}:=$ consumption of capitalist household.

Aggregate consumption is then distributed among the different consumption goods, $C_{z}$, according to a CES function:

$$
\begin{gathered}
\frac{P_{C}}{\bar{P}_{C}}=\left[\sum_{z} \theta_{z}^{C}\left(\frac{p_{c, z}\left(1+t_{c, z}\right)}{\bar{p}_{c, z}\left(1+\bar{t}_{c, z}\right)}\right)^{1-\sigma_{c}}\right]^{\frac{1}{1-\sigma_{c}}}, \\
\frac{C_{z}}{\bar{C}_{z}}=\frac{C}{\bar{C}}\left(\frac{P_{C}}{\bar{P}_{C}} \frac{\bar{p}_{z, c}}{p_{z, c}}\right)^{\sigma_{c}},
\end{gathered}
$$

where

$$
\begin{aligned}
& P_{C}:=\text { consumer price index } \\
& \theta_{z}^{C}:=\text { benchmark value share of consumption good } z \\
& p_{c, z}:=\text { producer price of consumption good } z \\
& t_{c, z}:=\text { consumption tax } \\
& \sigma_{c}:=\text { elasticity of substitution in consumption, } \\
& C_{z}:=\text { consumption of good } z \\
& C:=\text { aggregate consumption. }
\end{aligned}
$$

Each consumption good, $C_{z}$, is composed of the Armington goods (see Section 2.5) in fixed proportions:

$$
\frac{A_{s, z}}{\bar{A}_{s, z}}=\frac{C_{z}}{\bar{C}_{z}}
$$

with

$$
\sum_{s} A_{s, z}=C_{z} .
$$




\subsection{Labour Market}

\subsubsection{Wage Bargaining}

Wages are determined by sector-specific bargaining between the representative firm and a trade union. As is usual in the trade union literature, we represent the bargaining outcome as the maximisation of a Nash function that includes the objective functions of both parties and their respective fallback options. We adopt the "right to manage" approach: parties bargain over wages, and firms decide over their labour demand at the bargained wage.

The Nash bargaining solution is obtained by solving the following optimization problem:

$$
\max _{w_{H, s}, w_{L, s}} \ln \Omega_{s}=\ln \pi_{s}+\rho_{H, s} \ln \Gamma_{H, s}+\rho_{L, s} \ln \Gamma_{L, s},
$$

where

$\Omega_{s} \quad:=$ Nash maximand,

$\pi_{s}:=$ profits of representative firm,

$\Gamma_{i, s}:=$ union utility of workers of type $i$,

$\rho_{H, s}:=$ bargaining power of high-skilled labour,

$\rho_{L, s}:=$ bargaining power of low-skilled labour.

The firms' objective is their profit, $\pi_{s}$. We assume that the firms' fallback option is not to produce and, thus, make zero profits. The union represents both types of workers. For each skill type, its objective function is employment times the value of a job minus the value of unemployment:

$$
\Gamma_{i, s}=L_{i, s}\left(V_{i, s}-V_{U, i}\right)
$$

For a more detailed explanation of the term $V_{i, s}-V_{U, i}$ see Section 2.3.2.

Maximising the Nash objective (31) yields one first order condition (FOC) for each skill group and sector:

$$
\frac{\partial \pi_{s}}{\partial w_{i, s}} \frac{1}{\pi_{s}}=\rho_{H, s} \frac{\partial \Gamma_{H . s}}{\partial w_{i, s}} \frac{1}{\Gamma_{H, s}}+\rho_{L, s} \frac{\partial \Gamma_{L, s}}{\partial w_{i, s}} \frac{1}{\Gamma_{L, s}} .
$$


We use uncompensated own- and cross-price labour demand elasticities, $\eta_{i j}$, to write down the FOC in a compact form. Both bargaining parties know that firms will increase their output price when wages rise, leading to a fall in output. Note that in collective bargaining, the relevant output price elasticity is the elasticity of industry output, not the individual firm's output. The nesting structure of both production and consumption requires a numerical approximation of the relevant price elasticities. We calculate the latter at the benchmark point and use these values as parameters in subsequent policy counterfactuals. (The documentation of the numerical routine can be obtained from the authors upon request.) In our policy simulations, re-calculation of elasticities in the counterfactual equilibrium justifies this procedure because the deviations from the benchmark values are negligible.

The FOC for low-skilled labour in compact form then is

$$
\frac{-L_{L, s}\left(1+t_{l, s}\right)}{\pi_{s}}=\rho_{L, s}\left(\frac{\eta_{L L}, s}{w_{L, s}}+\frac{1-t_{w m, L}}{\tilde{w}_{L, s}-r V_{U, L}}\right)+\rho_{H, s} \frac{\eta_{H L}}{w_{H, s}} .
$$

For high-skilled labour, the FOC is derived analogously. (Taxes are explained in Section 2.4.)

\subsubsection{Intersectoral Mobility and Wage Arbitrage}

As is common in the literature on search unemployment (see e.g. Pissarides, 1990), we use value functions to characterize the surplus from working. The value of a job in sector $s$ in period $t, V_{s, t}$, can be expressed recursively as

$$
V_{s, t}=\frac{1}{1+r}\left[\tilde{w}_{s}+\left(1-\mu_{s}\right) V_{s, t+1}+\mu_{s} V_{U, t+1}\right]
$$

(we drop the skill index in this section), where

$$
\begin{aligned}
& r:=\text { discount rate } \\
& \tilde{w}_{s}:=\text { after-tax wage, } \\
& \mu_{s}:=\text { separation rate }
\end{aligned}
$$

The value of the state of unemployment, $V_{U, t}$, is expressed analogously:

$$
V_{U, t}=\frac{1}{1+r}\left[b+\left(1-\lambda_{s}\right) V_{U, t+1}+\lambda_{s} V_{s, t+1}\right]
$$


where

$b \quad:=$ unemployment benefit,

$\lambda_{s}:=$ hiring rate.

While unemployed, a worker receives a benefit that does not depend on former earnings. (But it can be indexed to the net wage in general and take on the form of a fixed replacement rate.)

A steady state is characterised by

$$
V_{s, t}=V_{s, t+1} \quad \text { and } \quad V_{U, t}=V_{U, t+1},
$$

which allows us to drop the time index and rewrite the value of the state of unemployment as

$$
r V_{U}=b+\lambda_{s}\left(V_{s}-V_{U}\right) \quad \forall s .
$$

In equilibrium, job-seekers must be indifferent between any two of the sectors, i.e.

$$
\lambda_{s}\left(V_{s}-V_{U}\right)=\lambda_{s s}\left(V_{s s}-V_{U}\right) \quad \forall s, s s .
$$

The higher the "surplus from working" $\left(V_{s}-V_{U}\right)$ is, the lower the quit rate from unemployment, $\lambda_{s}$, must be (see Acemoglu 2001, p. 18: "Workers who apply to bad jobs suffer shorter unemployment spells"). This condition reflects empirical evidence that high-wage jobs actually attract longer queues (Holzer et al. 1991).

In a steady state, there must be a flow equilibrium on the labour market, i.e. lay-offs equal hirings:

$$
\mu_{s}\left(1-u_{s}\right)=\lambda_{s} u_{s}
$$

where $u_{s}$ is the sectoral unemployment rate. This allows the elimination of $\lambda_{s}$ from the value functions:

$$
\lambda_{s}=\frac{\mu_{s}\left(1-u_{s}\right)}{u_{s}}
$$

We assume each single sector to be small compared to the aggregate economy, i.e. the bargaining parties treat the macro variables as given. In particular, the value of unemployment is constant from each union's point of view. We can thus replace $V_{s}-V_{U}$ in the Nash maximand with

$$
V_{s}-V_{U}=\frac{\tilde{w}_{s}-r V_{U}}{r+\mu_{s}}
$$


which results in a function where $\tilde{w}_{s}$ is the only remaining variable. The differentiation of the rearranged Nash objective yields the FOC for low-skilled and high-skilled labour as given in (33).

\subsection{Government}

The government levies the following taxes to collect revenues:

$t_{l, s}:=$ social security contributions of labour (payroll tax),

$t_{k, s}:=$ capital input tax,

$t_{\pi} \quad:=$ profit tax,

$A_{i} \quad:=$ allowable tax deduction,

$t_{w m, i}:=$ marginal tax rate on labour income,

$t_{c, z}:=$ consumption tax,

$t_{y, s}:=$ output tax.

Imposition of these taxes on the respective tax bases yields tax revenues:

$$
\begin{aligned}
T=\sum_{s} t_{k, s} r K_{s}+\sum_{s} t_{\pi} \pi_{s}+\sum_{i, s}\left[\left(t_{l, s}+t_{w m, i}\right) w_{i, s}-t_{w m, i} A_{i}\right] L_{i, s}+ \\
\sum_{z} t_{c, z} p_{c, z} C_{z}+\sum_{s} t_{y, s} p_{y, s} Y_{s} .
\end{aligned}
$$

The government's budget, then, is

$$
\sum_{s} p_{a, s} G_{s}+\sum_{i} \frac{u_{i}}{1-u_{i}} L_{i} b_{i}+x \overline{B O P}=T+\bar{T}_{L S}
$$

where

$G_{s}:=$ government purchases in sector $s$,

$x \quad:=$ foreign exchange rate,

$\overline{B O P}:=$ exogenous balance of payment deficit (or surplus, if negative),

$\bar{T}_{L S} \quad:=$ lump sum tax (or transfer, if negative) to balance the budget.

The value of $\bar{T}_{L S}$ is calibrated to assure the government's budget constraint in the benchmark. $\bar{T}_{L S}$ is then distributed among the three households in proportion to their monetary incomes. 


\subsection{Foreign Trade}

Domestically produced goods are converted through a constant elasticity of transformation (CET) function into specific goods destined for the domestic market and goods destined for the export market:

$$
\frac{Y_{s}}{\bar{Y}_{s}}=\left[\theta_{s}^{Y D}\left(\frac{D_{s}}{\bar{D}_{s}}\right)^{\frac{1+\eta}{\eta}}+\theta_{s}^{E x}\left(\frac{E x_{s}}{\overline{E x}_{s}}\right)^{\frac{1+\eta}{\eta}}\right]^{\frac{\eta}{1+\eta}},
$$

with an associated price equation

$$
\frac{p_{y, s}\left(1+t_{y, s}\right)}{\bar{p}_{y, s}\left(1+\bar{t}_{y, s}\right)}=\left[\theta_{s}^{Y D}\left(\frac{p_{d, s}}{\bar{p}_{d, s}}\right)^{1+\eta}+\theta_{s}^{E x}\left(\frac{x \cdot p_{E x, s}}{\bar{x} \cdot \bar{p}_{E x, s}}\right)^{1+\eta}\right]^{\frac{1}{1+\eta}},
$$

where

$D_{s} \quad:=$ good produced for the domestic market,

$E x_{s}:=$ goods produced for the export market,

$\theta_{s}^{Y D}:=$ value share of domestic consumption in domestic production,

$\theta_{s}^{E x}:=$ value share of exports,

$p_{d, s}:=$ price of $D_{s}$,

$p_{E x, s}:=$ export prices,

$\eta \quad:=$ elasticity of transformation,

$x \quad:=$ foreign exchange rate.

Following the small open economy assumption, export and import prices in foreign currency are not affected by the behaviour of the domestic economy. In other words, the small open economy faces infinitely elastic world export demand and world import supply functions.

Analogously to the export side, we adopt the Armington assumption of product heterogeneity for the import side. A CES function characterises the choice between imported and domestically produced varieties of the same good:

$$
\frac{A_{s}}{\bar{A}_{s}}=\left[\theta_{s}^{A D}\left(\frac{D_{s}}{\bar{D}_{s}}\right)^{\frac{1-\sigma_{s}^{I m}}{\sigma_{s}^{I m}}}+\theta_{s}^{A M}\left(\frac{I m_{s}}{\overline{I m}_{s}}\right)^{\frac{1-\sigma_{s}^{I m}}{\sigma_{s}^{I m}}}\right]^{\frac{\sigma_{s}^{I m}}{1-\sigma_{s}^{I m}}}
$$




$$
\frac{p_{a, s}}{\bar{p}_{a, s}}=\left[\theta_{s}^{A D}\left(\frac{p_{d, s}}{\bar{p}_{d, s}}\right)^{1-\sigma_{s}^{I m}}+\theta_{s}^{A M}\left(\frac{x p_{I m, s}}{\bar{x} \bar{p}_{I m, s}}\right)^{1-\sigma_{s}^{I m}}\right]^{\frac{1}{1-\sigma_{s}^{I m}}}
$$

where

$$
\begin{array}{ll}
A_{s} & :=\text { Armington good, } \\
\theta_{s}^{A D} & :=\text { value share of domestic production in domestic consumption, } \\
\theta_{s}^{A M} & :=\text { value share of imports, } \\
I m_{s} & :=\text { Imports, } \\
\sigma_{s}^{I m} & :=\text { elasticity of substitution, } \\
p_{a, s} & :=\text { price of Armington good, } \\
p_{I m, s} & :=\text { import prices (fixed in foreign currency). }
\end{array}
$$

The Armington good enters intermediate and final demand. The associated market clearing condition is

$$
A_{s}=\sum_{z} A_{s, z}+G_{s}+I_{s}+\sum_{s s} A_{s, s s}
$$

where

$A_{s, z}:=$ derived Armington demand from private consumption,

$G_{s} \quad:=$ government consumption,

$I_{s} \quad:=$ investment demand,

$A_{s, s s}:=$ intermediate demand from sector $s s$.

The market clearing condition for the domestically produced good destined for the home market is

$$
\frac{Y_{s}}{\bar{Y}_{s}}\left(\frac{p_{y, s}\left(1+t_{y, s}\right)}{\bar{p}_{y, s}\left(1+\bar{t}_{y, s}\right)} \frac{\bar{p}_{d, s}}{p_{d, s}}\right)^{-\eta}=\frac{A}{\bar{A}}\left(\frac{p_{a, s}}{\bar{p}_{a, s}} \frac{\bar{p}_{d, s}}{p_{d, s}}\right)^{\sigma_{s}^{m}} .
$$

Foreign closure of the model is warranted through the balance of payments constraint:

$$
\overline{B O P}+\sum_{s} \overline{E x}_{s} \frac{Y_{s}}{\bar{Y}_{s}}\left(\frac{p_{y, s}\left(1+t_{y, s}\right)}{\bar{p}_{y, s}\left(1+\bar{t}_{y, s}\right)} \frac{\bar{x}}{x}\right)^{-\eta}=\sum_{s} \bar{M}_{s} \frac{A}{\bar{A}}\left(\frac{p_{a}}{\bar{p}_{a}} \frac{\bar{x}\left(1+\bar{t}_{m, s}\right)}{x\left(1+t_{m, s}\right)}\right)^{\sigma_{s}^{m}} .
$$

The flexible exchange rate, $x$, adjusts so as to leave the benchmark balance of payments deficit (or surplus), $\overline{B O P}$, unchanged in terms of world market prices. 


\section{Policy Simulations}

We use our model to investigate the labour market effects of stylised tax policy reforms for Germany, an economy that features decentralized sectoral wage bargaining. Before we can perform quantitative analysis, the free parameters of the functional forms must be determined. As is customary in applied general equilibrium analysis, the model is based on economic transactions in a particular benchmark year. Benchmark quantities and prices - together with exogenous elasticities - are used to calibrate the functional forms. Appendix II provides a detailed description of the data sources and the calibration procedure.

Our policy scenarios are designed to provide a straightforward comparison of four tax instruments that are repeatedly addressed in the policy debate on tax reforms. Three of these instruments directly affect the cost of labour: (1) the payroll tax (scenario $\left.t_{l}\right)$, (2) the marginal labour income tax (scenario $t_{m}$ ), and (3) the tax allowance (scenario $A$ ). As a fourth instrument, we consider the consumption tax (scenario $\left.t_{c}\right)$.

Across all scenarios, we impose revenue-neutrality in the sense that the provision of the public goods is kept constant at the benchmark level. Constant public good provision together with the assumption of separability between private and public good consumption provides a common approach to avoid measurement problems with respect to the benefits from public good consumption. Cutbacks in labour or consumption taxes are compensated by an increase of lump-sum transfers from households to the government. The compensating transfers are distributed proportionally to the benchmark household incomes (whose benchmark shares in total income are $46 \%$ for capital owners, $48 \%$ for high skilled workers and $6 \%$ for low skilled workers). The comparability of results across the scenarios is warranted because we maintain this (somewhat arbitrary) distribution of lump-sum transfers and implement a uniform increase in the overall lump-sum transfer (two percent of the total benchmark public budget), while the additional public revenue is recycled through a reduction of each of the four taxes that we consider.

In Section 3.1, we discuss the results of our four central scenarios. In Section 3.2, we check the robustness of our results with respect to changes in two key assump- 
tions: (1) fixed absolute real unemployment benefits instead of a fixed replacement rate and (2) internationally mobile capital instead of a domestically fixed capital stock.

\subsection{Main Scenarios}

Tables 1 and 2 summarise the impacts of the simulated tax policy reforms on central economic indicators. The simulation results are reported in percentage change from benchmark values, except for the indicators unemployment and tax parameters, whose changes are reported in percentage points. Table 1 refers to a situation in which labour supply is fixed at the benchmark value, whereas Table 2 is based on the assumption of elastic labour supply (with an uncompensated labour supply elasticity amounting to 0.15 for both worker households (see Borjas 2000, p. 47)). A comparison of Tables 1 and 2 then allows us to isolate the effects of tax parameter changes in the wage bargaining system independent of general equilibrium labour supply reactions.

For the interpretation of results, it is crucial to consider how the wage tax parameters affect the progression of labour income taxation. With $I$ denoting wage income of the worker household, the average tax rate of the linear-progressive tax schedule is endogenously determined:

$$
t_{w}=t_{m} \frac{(I-A)}{I}
$$

The degree of tax progression is measured by the coefficient of residual income progression ("CRIP"), which is defined as $\left(1-t_{m}\right) /\left(1-t_{w}\right)$, . In the case of proportional taxation, $A$ is zero and $t_{w}$ equals $t_{m}$, yielding a $C R I P=1$, i.e. a situation without progression. With a positive tax allowance, the labour income tax schedule becomes progressive, and the degree of progressivity rises (i.e. the $C R I P$ decreases) the higher the tax allowance is. As with $A$, cuts in $t_{m}$ have a direct effect on tax progression: If the marginal tax rate is cut, the $C R I P$ increases (for $A>0$ ), i.e. the tax schedule becomes less progressive. The payroll tax $\left(t_{l}\right)$, in contrast, only has an indirect effect on tax progression through variations of the wage income. This 
indirect income effect, which is also present in the cases of $t_{m}, A$, and $t_{c}$, turns out to be negligible in the numerical simulations.

\begin{tabular}{||l|r|r|r|r||}
\hline \hline Instrument & \multicolumn{1}{|c|}{$t_{l}$} & \multicolumn{1}{c|}{$t_{m}$} & \multicolumn{1}{c|}{$A$} & \multicolumn{1}{c|}{$t_{c}$} \\
\hline GDP & -0.02 & -0.13 & 0.15 & -0.02 \\
Consumption & 0.29 & 0.37 & 0.15 & 0.14 \\
Investment & -0.77 & -1.43 & 0.31 & -0.39 \\
Welfare (L) & 0.65 & 0.40 & 0.08 & 0.31 \\
Welfare (H) & 0.60 & 0.90 & 0.23 & 0.29 \\
Welfare (K) & -0.78 & -1.35 & 0.17 & -0.38 \\
Employment (L) & -0.03 & -0.22 & 0.31 & -0.03 \\
Employment (H) & -0.02 & -0.17 & 0.21 & -0.02 \\
Unemployment (L) & 0.02 & 0.19 & -0.26 & 0.02 \\
Unemployment (H) & 0.02 & 0.15 & -0.19 & 0.02 \\
Interest rate & 0.03 & -0.61 & 1.08 & 1.18 \\
Producer wage (L) & -0.03 & 0.25 & -0.52 & 0.01 \\
Producer wage (H) & -0.02 & 0.39 & -0.70 & 0.01 \\
Consumer wage (L) & 1.64 & 2.27 & -0.52 & 1.21 \\
Consumer wage (H) & 1.65 & 3.16 & -0.70 & 1.22 \\
Tax parameter change (L) & -2.03 & -1.55 & 4.91 & -1.19 \\
Tax parameter change (H) & -2.03 & -1.96 & 4.76 & -1.19 \\
\hline \hline
\end{tabular}

Table 1: Changes in Macroeconomic Variables (Fixed Labour Supply)

When the payroll tax $t_{l}$ is lowered, the tax progressivity (measured as the $C R I P$ ) remains virtually unchanged. One might expect a reduction in the tax wedge between the producer wage and the consumer wage to result in a symmetrical movement of these two wages. However, in a model with a fixed replacement rate, the reaction is asymmetrical: The adjustment takes place through the net wage, whereas the gross wage remains nearly unchanged. The reason for this is that - given a fixed replacement rate - the outside option of the trade union moves in proportion to the bargained wage. The bargaining first-order condition can only hold with (nearly) constant unemployment and thus with a constant producer wage (Pissarides 1998, p.157). In essence, all policy changes that "do not affect the difference between the 
after-tax wage income and the after-tax unemployment income" (i.e. the outside option) will have no effect on wage formation (Koskela 2001, p.12).

The increase in consumer wages more than offsets the reduction in lump-sum transfers for the worker households, which implies an increase in real income (welfare) for workers. On the other hand, capitalists suffer welfare losses since the increase in their factor income is not high enough to compensate their expenditure for the additional lump-sum transfers (the change in the interest rate is negligible). As capitalists have a higher savings ratio than workers, the income redistribution from capitalists to workers translates into a shift from investment to consumption.

When the marginal wage tax rate $t_{m}$ is lowered, tax progressivity declines. It becomes more attractive for the trade unions to bargain for higher wages instead of more employment. Consequently, the producer wages go up, generating lower employment (higher unemployment) and less overall economic activity (measured as GDP). Although the tax base of the wage tax is smaller than that of the payroll tax because of the tax allowance, the tax cut is smaller in terms of tax rate changes (1.55 and 1.96 percentage points vis-à-vis 2.03 percentage points, respectively). This is because the tax rate change leads to contraction of all tax bases in the economy. Similar to the payroll tax scenario, we have functional redistribution from capitalists to workers.

When the wage income tax allowance $A$ is used to compensate for the exogenous increase in lump-sum transfers, the allowance must be increased by about 4.5 percentage points of the benchmark wage income. The wage income tax schedule then becomes more progressive, which triggers labour market effects that are inverse to the case where $t_{m}$ is cut. The producer wage goes down, leading to higher employment and lower unemployment. Again, the representative worker households benefit directly from the tax reform, but now this is not through a higher consumer wage, but through higher disposable income in spite of a lower consumer wage. Contrary to the other two labour tax scenarios, in the case of the wage tax allowance, the capitalists gain as well, because the increase in the interest rate more than offsets their higher lump-sum transfers to the government. Consequently, the redistributive effects are considerably smaller than in the other scenarios $t_{l}$.and $t_{m}$.

When the consumption tax is lowered, the results are very similar to the payroll 
tax scenario. This is not surprising, because these two taxes are nearly equivalent in a model setting where future consumption depends on static consumer price expectations. Yet, compared to the payroll tax scenario, the redistributive effect is less pronounced because capital owners directly benefit from the consumption tax cut, whereas this is not the case with the payroll tax. The increase of the real interest rate reflects the decrease in consumer prices (the consumer price index serves as numéraire). The cut in consumption taxes in Table 1 is reported as a uniform decrease in the tax factor $1+t_{c}$. Consumption tax rates are non-uniform across consumption goods in the benchmark, and we have chosen a proportional downscaling of the tax factor in order to preserve the consumption tax structure.

\begin{tabular}{||l|r|r|r|r||}
\hline \hline Instrument & \multicolumn{1}{|c|}{$t_{l}$} & \multicolumn{1}{c|}{$t_{m}$} & \multicolumn{1}{c|}{$A$} & \multicolumn{1}{c|}{$t_{c}$} \\
\hline GDP & 0.19 & 0.11 & 0.32 & 0.17 \\
Consumption & 0.10 & 0.16 & -0.01 & -0.02 \\
Investment & 0.62 & 0.12 & 1.44 & 0.81 \\
Welfare (L) & 0.08 & -0.08 & -0.24 & -0.10 \\
Welfare (H) & -0.14 & 0.01 & -0.32 & -0.28 \\
Welfare (K) & 0.44 & 0.00 & 1.16 & 0.66 \\
Employment (L) & 0.33 & 0.14 & 0.58 & 0.29 \\
Employment (H) & 0.28 & 0.17 & 0.46 & 0.25 \\
Unemployment (L) & -0.01 & 0.13 & -0.27 & -0.01 \\
Unemployment (H) & 0.01 & 0.13 & -0.19 & 0.00 \\
Interest rate & 1.33 & 0.84 & 2.13 & 2.24 \\
Producer wage (L) & -0.54 & -0.28 & -0.90 & -0.45 \\
Producer wage (H) & -0.84 & 0.53 & -1.36 & -0.71 \\
Consumer wage (L) & 0.96 & 1.55 & -0.92 & 0.65 \\
Consumer wage (H) & 0.65 & 1.97 & -1.38 & 0.38 \\
Tax parameter change (L) & -1.85 & -1.42 & 4.70 & -1.10 \\
Tax parameter change (H) & -1.85 & -1.80 & 4.69 & -1.10 \\
\hline \hline
\end{tabular}

Table 2: Changes in Macroeconomic Variables (Flexible Labour Supply)

We now turn to the implications of flexible labour supply as captured in Table 2. In general, we can observe that unemployment rates are hardly affected by whether 
labour supply is flexible or fixed. This confirms economic intuition for a wage bargaining framework with a fixed replacement rate where - in the simplest analytical case - the rate of unemployment is solely determined through the CRIP and the replacement rate (Boeters, 2002). However, the employment level differs considerably between the cases with fixed and flexible labour supply. Compared with Table 1, there is an additional expansionary labour supply effect in Table 2, which translates into higher output across all four tax reform scenarios. This effect cannot be traced back to one single source but is the result of overlapping price and income effects. On the one hand, there is a price effect due to the higher value of searching for work (through a higher consumption wage or a higher tax allowance on labour income) and an income effect due to the higher lump-sum transfer to the government, both of which work towards higher labour supply. On the other hand, there is an opposite income effect due to the higher consumption wage. Observing higher employment in the case with flexible labour supply than with fixed labour supply, we can infer that the former effects dominate the labour supply decision. Higher labour supply at a constant unemployment rate then translates into higher capital productivity and a higher interest rate. Capital owners are therefore better off in all scenarios in Table 2 than in Table 1. (Note that the welfare of worker households cannot be compared between Tables 1 and 2, because leisure enters the welfare determination with flexible labour supply, whereas it does not with fixed labour supply.)

In summary, the results from our stylised policy scenarios suggest that tax policy shifts do not provide a strong lever for alleviating of the unemployment problem.

\subsection{Sensitivity Analysis}

For our main scenarios in Section 3.1 we have assumed that (1) unemployment benefit are given as a fixed replacement rate of the disposable income of the employed workers and (2) capital can not move across domestic borders. In this section, we explore the robustness of our results with respect to plausible alternative assumptions on the institutional setting for unemployment benefits and capital mobility.

Table 3 summarizes results generated under the assumption that the unemployment benefit is fixed in absolute, real terms rather than by a constant replace- 
ment rate (labour supply is flexible, so Table 3 must be compared to Table 2). Across all tax instruments, the alternative determination of the unemployment benefit generates an expansive effect with lower unemployment, higher employment and higher output. When tax reforms tend to produce a higher disposable labour income (through an increase in the consumer wage or through a higher tax allowance), the unemployed are worse off when they cannot participate in this income increase through an adjustment of their unemployment benefits. This in turn produces a downward pressure on the bargained wage, because it becomes relatively more attractive for the trade union to negotiate for higher employment instead of higher wages. As a consequence, the bargained wages and unemployment in this setting are lower than with a fixed replacement rate.

\begin{tabular}{||l|r|r|r|r||}
\hline \hline Instrument & \multicolumn{1}{c|}{$t_{l}$} & \multicolumn{1}{c|}{$t_{m}$} & \multicolumn{1}{c|}{$A$} & \multicolumn{1}{c|}{$t_{c}$} \\
\hline GDP & 0.28 & 0.22 & 0.36 & 0.22 \\
Consumption & 0.03 & 0.07 & -0.04 & -0.07 \\
Investment & 1.18 & 0.84 & 1.69 & 1.14 \\
Welfare (L) & -0.10 & -0.22 & -0.31 & -0.22 \\
Welfare (H) & -0.26 & -0.16 & -0.37 & -0.35 \\
Welfare (K) & 0.93 & 0.64 & 1.38 & 0.95 \\
Employment (L) & 0.63 & 0.39 & 0.69 & 0.49 \\
Employment (H) & 0.39 & 0.32 & 0.51 & 0.30 \\
Unemployment (L) & -0.31 & -0.11 & -0.39 & -0.20 \\
Unemployment (H) & -0.12 & -0.05 & -0.25 & -0.07 \\
Interest rate & 1.85 & 1.51 & 2.36 & 2.59 \\
Producer wage (L) & -0.95 & -0.61 & -1.06 & -0.71 \\
Producer wage (H) & -1.15 & -0.95 & -1.50 & -0.88 \\
Consumer wage (L) & 0.64 & 1.36 & -1.08 & 0.42 \\
Consumer wage (H) & 0.44 & 1.76 & -1.52 & 0.25 \\
Tax parameter change (L) & -1.98 & -1.55 & 4.86 & -1.14 \\
Tax parameter change (H) & -1.98 & -1.96 & 4.89 & -1.14 \\
\hline \hline
\end{tabular}

Table 3: Changes in Macroeconomic Variables (Fixed Real Unemployment Benefits) The welfare level of the representative worker households in Table 3 is lower 
than in Table 2 for all tax reform scenarios. This means that the positive income effect through higher employment is more than offset by the negative income effects through a lower wage and lower unemployment benefits. With respect to functional income distribution, granting unemployment benefits in fixed absolute real terms rather than linking it to a constant replacement rate triggers a redistributional effect from workers to capital owners. Overall, the ranking of the three labour tax instruments in terms of output, employment and unemployment remains the same as in Table 2 (whereas the effects of $t_{c}$ now come closer to those of $t_{m}$ than of $t_{l}$ ).

Table 4 summarizes the results for the assumption of internationally mobile capital (while the unemployment benefit is - by default - determined through a fixed replacement rate). The international capital price is fixed at the level of the exchange rate, so that the entries in row "Interest rate" of Table 4 reflect the relative movement of the exchange rate to the consumption price index. The domestic capital stock is now adjusted by capital inflows or outflows such that its marginal product equals the exogenous international price of capital. Since we observe an increase in the domestic interest rate for all scenarios with a fixed capital stock (Table 2), this translates into capital inflows for the case of capital mobility.

Compared to Table 2, Table 4 generally features higher output levels which are triggered by additional capital inflows from abroad. More capital leads to higher labour productivity which translates into higher wages. International capital mobility, thus, induces strong income redistribution from capitalists to workers. Domestic capital owners cannot - as with a fixed capital stock - benefit from an increase in the real interest rate; their factor income remains roughly constant, but they suffer on the expenditure side from the increase in the lump-sum transfer to the government. Workers, on the other hand, are more than compensated through higher wages.

In terms of output and employment, the ranking among the different tax instruments remains stable. The wage income tax allowance performs best, and the marginal tax rate ranks last; the payroll tax together with the consumption tax is in-between. However, in terms of tax policy incidence, the ranking of tax instruments changes when we alter the assumption about capital mobility. The wage income tax allowance is the worst scenario for the worker households under capital immobility, whereas it is the best possible outcome under international capital mobility. Cap- 


\begin{tabular}{||l|r|r|r|r||}
\hline \hline Instrument & \multicolumn{1}{|c|}{$t_{l}$} & \multicolumn{1}{c|}{$t_{m}$} & \multicolumn{1}{c|}{$A$} & \multicolumn{1}{c|}{$t_{c}$} \\
\hline GDP & 0.35 & 0.20 & 0.67 & 0.30 \\
Consumption & 0.74 & 0.56 & 1.12 & 0.48 \\
Investment & -0.66 & -0.72 & -0.53 & -0.20 \\
Welfare (L) & 0.65 & 0.24 & 0.68 & 0.34 \\
Welfare (H) & 0.57 & 0.46 & 0.90 & 0.27 \\
Welfare (K) & -0.67 & -0.73 & -0.55 & -0.21 \\
Employment (L) & 0.33 & 0.12 & 0.69 & 0.28 \\
Employment (H) & 0.34 & 0.19 & 0.66 & 0.29 \\
Unemployment (L) & 0.08 & 0.21 & -0.22 & 0.07 \\
Unemployment (H) & 0.06 & 0.18 & -0.18 & 0.05 \\
Interest rate & 0.10 & 0.03 & 0.24 & 1.42 \\
Producer wage (L) & 0.02 & 0.10 & -0.05 & 0.02 \\
Producer wage (H) & -0.06 & -0.02 & -0.17 & -0.05 \\
Consumer wage (L) & 1.91 & 2.20 & -0.04 & 1.36 \\
Consumer wage (H) & 1.84 & 2.87 & -0.15 & 1.29 \\
Tax parameter change (L) & -2.30 & -1.62 & 6.29 & -1.32 \\
Tax parameter change (H) & -2.30 & -2.06 & 6.04 & -1.32 \\
\hline \hline
\end{tabular}

Table 4: Changes in Macroeconomic Variables (Mobile Capital)

ital owners, by contrast, are best off with an adjustment of the wage income tax allowance under immobile capital, whereas their preferred instrument under capital mobility is the consumption tax.

\section{Conclusions}

High taxes on labour combined with institutional rigidities of the labour market are often held responsible for substantial structural unemployment in various OECD countries. In this vein, cuts in labour taxes are considered as a potentially important policy measure to alleviate the unemployment problem. In this paper, we developed an applied general equilibrium model that allows us to assess the quantitative ef- 
fects of tax policy shifts in economies featuring decentralised wage bargaining. A distinctive and innovative feature of our model is the sectoral heterogeneity in wage bargaining between employers' associations and trade unions that represent workers of two skill groups with different bargaining power. Illustrative policy simulations for Germany show that the reduction in unemployment that can be achieved by tax reforms is rather moderate. Labour market effects can mainly be traced back to changes in the tax progression.

Sensitivity analysis with respect to assumptions on the institutional setting for unemployment benefits and on capital mobility shows that the ranking of tax policy instruments in terms of output and employment remains stable. Regarding welfare, the ranking is rather robust with respect to the institutional setting for the unemployment benefits, but it is highly sensitive to the assumption on capital mobility. With internationally mobile capital, workers can substantially benefit from capital imports through higher wages, whereas capitalists no longer benefit from higher rental rates of capital (the latter being fixed at the benchmark level). International factor mobility is thus of great importance for the distributional consequences of the tax reforms we analysed.

There are various aspects missing from our modelling framework that are potentially important when we assess the prominent role of tax progression in our tax policy reforms: (1) An endogenous decision on working hours may substantially reduce or even invert the employment effects of tax progression (see Sørensen 1999, Fuest and Huber 2000). (2) Taxation has a strong impact on the attractiveness of the informal sector. Black market work that contributes to official unemployment becomes more attractive the higher the marginal labour income tax rates are.

(3) Taxation affects endogenous decisions about human capital (Fuest and Huber 1998), which in turn feed back to the level of unemployment. (4) As compared to skill groups in labour markets with collective wage bargaining, tax policies might work quite differently for the segment of the highest skilled workers in competitive labour markets.

We plan to address these issues in future research developing the current model to the extent possible with the available data. 


\section{References}

[1] Abowd, John M., Kramarz, Francis, Margolis, David N. (1999): High Wage Workers and High Wage Firms, Econometrica, 67, 251-333

[2] Acemoglu, Daron (2001): Good Jobs versus Bad Jobs, Journal of Labor Economics, 19, 1-21

[3] Ballard, Charles (2000): How many hours are in a simulated day? The effects of time endowment on the results of tax-policy simulation models, Discussion Paper, Michigan State University

[4] Ballard, Charles L., Don Fullerton, John B. Shoven and John Whalley (1985): A General Equilibrium Model for Tax Policy Evaluation; The University of Chicago Press; National Bureau of Economic Research

[5] Bernheim, Douglas B. (1999): Taxation and Saving, NBER Working Paper 7061

[6] Blanchflower, David G., and Andrew J. Oswald (1994): The Wage Curve, Cambridge (Mass.), London: MIT Press

[7] BMF (2000): http://www.bundesfinanzministerium.de/Anlage9419/Datensammlung-zur-Steuerpolitik.pdf

[8] Boeters, Stefan (2002): Tax Progressivity and the Trade Union's FallbackOption, ZEW Discussion Paper No. 02-15, Mannheim

[9] Böhringer, Christoph, Wolfgang Wiegard, Collin Starkweather and Anna Ruocco (2003): Green Tax Reforms and Computational Economics: A Do-ityourself Approach, Computational Economics, 22, 75-109

[10] Böhringer, Christoph, Thomas F. Rutherford and Wolfgang Wiegard (2003): Computable General Equilibrium Analysis: Opening a Black Box, ZEW Discussion Paper 03-56. Mannheim

[11] Bovenberg, A. Lans, Johan J. Graafland and Ruud A. de Mooij (2000): Tax reform and the Dutch labor market : an applied general equilibrium approach, Journal of Public Economics, 78, 193-214 
[12] Borjas, George J. (2000): Labor economics, 2nd ed., Boston, Mass.: McGrawHill

[13] Bundesbank (1999): Annual accounts of West-German enterprises (1971-1996)

[14] Bundesminister der Finanzen (1992): Bekanntmachung der Allgemeinen Lohnsteuertabellen 1993, Köln: Bundesanzeiger-Verl.-Ges.

[15] Buslei, Hermann, and Viktor Steiner (1999): Beschaeftigungseffekte von Lohnsubventionen im Niedriglohnbereich, Baden-Baden: Nomos

[16] EIRO (2002): Industrial relations in the EU, Japan and USA, 2001, http://www.eiro.eurofound.ie/2002/12/feature/TN0212101F.html

[17] Falk, Martin, and Bertrand Koebel (1997): The Demand of Heterogeneous Labour in Germany, ZEW Discussion Paper 97-28, Mannheim

[18] Fehr, Hans, and Wolfgang Wiegard (1996), Numerische Gleichgewichtsmodelle: Grundstruktur, Anwendungen und Erkenntnisgehalt, Ökonomie und Gesellschaft, Jahrbuch 13: Experiments in Economics, Frankfurt: CampusVerlag, 297-339

[19] Fuest, Clemens, and Bernd Huber (1998): Tax Progression and Human Capital in Imperfect Labour Markets, EPRU Discussion Paper 1998-03

[20] Fuest, Clemens, and Bernd Huber (2000): Is tax progressions really good for employment? A model with endogenous hours of work, Labour Economics, 7, 79-93

[21] Goerke, Laszlo (1997): Taxes in an efficiency wage economy in the short-run and in the long-run, Finanzarchiv, 54, 447-470

[22] Graafland, Johan J., Ruud A. de Mooij, André G.H. Nibbelink and Ate Nieuwenhuis (2001): MIMICing Tax Policies and the Labour Market, Amsterdam: Elsevier 
[23] Haisken-DeNew, John P. and Christoph M. Schmidt (1999): Industry wage differentials revisited: a longitudinal comparison of Germany and USA (19841996), IZA Discussion Paper, No. 98, Bonn

[24] Hamermesh, Daniel S. (1993): Labor Demand, Princeton, New Jersey: Princeton University Press

[25] Hoel, Michael (1990): Efficiency wages and income taxes, Journal of Economics, 51, 89-99

[26] Holzer, Harry, Lawrence Katz and Alan Krueger (1991): Job Queues and Wages, Quarterly Journal of Economics, 106, 739-768

[27] Hutton, John P., and Anna Ruocco (1999): Tax Reform and Employment in Europe, International Tax and Public Finance, 6, 263-287

[28] Kehoe, Patrick J., and Timothy J. Kehoe (1994): A Primer on Static Applied General Equilibrium Models, Federal Reserve Bank of Minneapolis Quarterly Review, Spring

[29] Koskela, Erkki (2001): Labour taxation and employment in trade uinion models: A partial survey, Bank of Finland Discussion Papers, No. 19

[30] Koskela, Erkki, and Jouko Vilmunen (1996): Tax progression is good for employment in popular models of trade union behaviour, Labour Economics, 3, $65-80$

[31] Layard, Richard, Stephen Nickell and Richard Jackman (1991): Unemployment: macroeconomic performance and the labour market, Oxford: Oxford Univ. Press

[32] Lockwood, Ben, and Alan Manning (1993): Wage setting and the tax system: theory and evidence for the United Kingdom, Journal of Public Economics, 52, $1-29$

[33] OECD (2001): OECD Employment Outlook, Paris 
[34] Pereira, Alfredo M, and John B. Shoven (1992), Survey of Dynamic Computational General Equilibrium Models for Tax Policy Evaluation, Journal of Policy Modeling, 10, 401-426

[35] Pissarides, Christopher A. (1990): Equilibrium unemployment theory, Oxford: Basil Blackwell

[36] Pissarides, Christopher A. (1998): The impact of employment tax cuts on unemployment and wages; The role of unemployment benefits and tax structure, European Economic Review 42, 155-183

[37] Rutherford, Thomas (1995): Constant Elasticity of Substitution Functions: Some Hints and Useful Formulae, Notes prepared for GAMS General Equilibrium Workshop in Boulder, Colorado (http://www.gams.com/solver/mpsge/ cesfun.htm)

[38] Shoven, John B., and John Whalley (1984): Applied General-Equilibrium Models of Taxation and International Trade: An Introduction and Survey, Journal of Economic Literature, 22, 1007-1051

[39] Shoven, John B., and John Whalley (1992), Applying General Equilibrium, Cambridge: Cambridge University Press

[40] SOEP Group (2001): The German Socio-Economic Panel (GSOEP) after more than 15 years - Overview. In: Elke Holst, Dean R. Lillard and Thomas A. DiPrete (eds.): Proceedings of the 2000 Fourth International Conference of German Socio-Economic Panel Study Users (GSOEP2000), Vierteljahrshefte zur Wirtschaftsforschung (Quarterly Journal of Economic Research), Vol. 70, No. $1,7-14$

[41] Sørensen, Peter B. (1997): Public Finance Solutions to the European Unemployment Problem?, Economic Policy 25, 223-264

[42] Sørensen, Peter B. (1999): Optimal Tax Progressivity in Imperfect Labour Markets, Labour Economics 6, 435-452 
[43] Statistisches Bundesamt (1995): Series FS 17, R 1, Wirtschaftsrechnungen ausgewählter privater Haushalte

[44] Welsch, Heinz (2001): Armington Elasticities and Product Diversity in the European Community: A Comparative Assessment of Four Countries, Working Paper, University of Oldenburg

[45] Weyant, John P. (ed) (1999), The Costs of the Kyoto Protocol: A Multi-Model Evaluation, The Energy Journal, Special Issue 


\section{Appendix : Calibrated Share Form}

Numerical calculation of an economic equilibrium requires the choice of concrete functional forms for production possibilities and preferences. In applied modelling, nested constant elasticity of substitution (CES) functions (including Leontief- or Cobb-Douglas-specifications as subcases) are most common. Such functions have certain mathematical properties (regularity) that ease the numerical analysis considerably, but are still flexible enough to allow for an appropriate representation of economic behaviour. CES functions are often written in coefficient form, which requires inverting demand functions to calculate free parameters from a given set of benchmark prices and quantities. The so-called calibrated share form, which is equivalent to the coefficient form (see Böhringer, Rutherford and Wiegard 2003), eases the calculation of free parameters, since it is based on value shares that can be directly read of from benchmark data without inverting the function. For example, the standard CES production function in calibrated share form reads as

$$
\frac{Y}{\bar{Y}}=\left[\sum_{i} \theta_{i}\left(\frac{X_{i}}{\bar{X}_{i}}\right)^{\frac{1-\sigma}{\sigma}}\right]^{\frac{\sigma}{1-\sigma}} .
$$

Associated is a dual cost function in calibrated share form:

$$
\frac{c_{y}}{\bar{c}_{y}}=\left[\sum_{i} \theta_{i}\left(\frac{p_{x, i}}{\bar{p}_{x, i}}\right)^{1-\sigma}\right]^{\frac{1}{1-\sigma}},
$$

and demands for the individual factors of production (applying Shepard's Lemma):

$$
\frac{X_{i}}{\bar{X}_{i}}=\frac{Y}{\bar{Y}}\left(\frac{c_{y}}{\bar{c}_{y}} \frac{\bar{p}_{x, i}}{p_{x, i}}\right)^{\sigma}
$$

where

$Y \quad:=$ output quantity,

$\theta_{i}:=$ benchmark value share of $X_{i}$ in the production of $Y$,

$X_{i}:=$ input factor,

$c_{y}:=$ cost of $Y$,

$p_{x, i}:=$ input price of $X_{i}$,

$\sigma \quad:=$ elasticity of substitution. 


\section{Appendix : Model Parameterisation}

This appendix lays out the parameterisation of our generic model described in Section 2 to German data.

\section{II.1 Data sources}

Our main data source is the input-output table (IOT) provided by the Federal Statistical Office of Germany for the benchmark year 1995, which contains a consistent data set of economic transactions for 59 sectors. Furthermore, we use complementary data from the employment statistics register and a sample of it (IABS), the Bundesbank (balance sheet data), and the federal government (tax statistics).

\section{II.2 Aggregation level}

For the sake of reduced dimensionality, we have aggregated the production side of the economy to seven sectors (see Table 5). The NACE sections A to P include all sectors of the German IOT.

\begin{tabular}{||l|l||}
\hline \hline Sectors in model & Single industries* \\
\hline Agriculture & Agriculture (A), Fishing (B) \\
Energy \& Mining & Mining (C), Electricity (E) \\
Manufacturing & Manufacturing (D) \\
Construction & Construction (F) \\
Trade \& Transport & Wholesale and retail trade (G), Transport (I) \\
Banking & Financial Intermediation (J), Real estate (K) \\
Other Services & Public administration (L), Education (M), \\
& Health (N), Other community activities (O), \\
& Hotels and restaurants (H), Private Households (P) \\
& $*$ Letters in parentheses indicate NACE-Code (section) \\
\hline \hline
\end{tabular}

Table 5: Sectoral Aggregation 


\section{II.3 Parameters}

Table 6 provides a list of key model parameters. In the remainder of this section, we explain how the value of these parameters has been chosen.

\begin{tabular}{||l|l||}
\hline \hline Symbol & Description \\
\hline$\beta_{s}^{i}$ & benchmark shares of factors that contribute to value added \\
$\sigma_{s}^{i}$ & elasticity of substitution (EOS) in production \\
$m_{s}$ & price mark-up \\
$\sigma_{i}^{l}$ & EOS between leisure and consumption \\
$\sigma_{c}$ & EOS between consumption goods \\
$\mu_{s}$ & separation rate \\
$b_{i} / \bar{w}_{i}$ & replacement ratio in benchmark \\
$\bar{u}_{i}$ & benchmark unemployment \\
$\eta$ & elasticity of transformation \\
& between production for domestic markets and exports \\
$\sigma_{s}^{m}$ & EOS between domestic production and imports \\
$\delta$ & depreciation rate \\
$\theta_{i}^{H}$ & value shares of savings and current utility \\
$\theta_{i}^{l}$ & value share of leisure and consumption \\
\hline \hline
\end{tabular}

Table 6: Model Parameters

\section{II.3.1 Cost shares of production factors and mark-up rates}

The German IOT provides a decomposition of total value-added into remuneration of capital and labour. For our model parameterisation, we must disaggregate the respective values into capital services and profits on the one hand, and labour incomes of the two skill groups on the other. To quantify profits, we use the German Federal Bank's (Bundesbank, 1999) publication on annual accounts of West-German enterprises. We take the profit per Euro of sales ratio (before tax) to measure profits. Expenses for capital services are calculated as the difference between total capital earnings and profits. Mark-up rates result as the ratio of profits over sales. To divide the total amount of labour earnings per sector into income of high-skilled and 
low-skilled workers, we employ data from the employment register (Beschäftigtenstatistik). This database covers all employees holding a regular job, i.e. those who have to pay social security contributions. An employee without a vocational or academic degree is treated as "unskilled".

\section{II.3.2 Elasticity of substitution in production}

Our main reference for elasticities of substitution in German production is Falk and Koebel (1997), who provide estimates for five aggregated sectors. Complementary information on factor price elasticities are taken from Buslei and Steiner (1999). Falk and Koebel (1997) treat capital as a flexible factor of production, whereas Buslei and Steiner (1999) treat it as quasi-fixed. Both papers use similar data, aggregation, however, differs between the two. Table 7 summarises the uncompensated price elasticities for labour demand that underlie our model simulations.

\begin{tabular}{||l|l|l|l|l||}
\hline \hline Industry & $\varepsilon_{L L}$ & $\varepsilon_{H H}$ & $\varepsilon_{L H}$ & $\varepsilon_{H L}$ \\
\hline Agriculture & -0.50 & -0.17 & 0.15 & 0.02 \\
Energy \& Mining & -0.21 & -0.11 & 0.08 & 0.01 \\
Manufacturing & -1.04 & -0.57 & 0.45 & 0.08 \\
Construction & -0.88 & -0.07 & 0.60 & 0.05 \\
Trade \& Transport & -0.22 & -0.16 & 0.02 & 0.00 \\
Banking & -0.75 & -0.13 & 0.18 & 0.01 \\
Other Services & -0.49 & -0.11 & 0.34 & 0.03 \\
\hline \hline
\end{tabular}

Table 7: Labour Demand Elasticities

\section{II.3.3 Calibration of $\zeta, \sigma_{i}^{l}$ and $\sigma_{i}^{s}$}

The ratio between the total time endowment and the time worked in the benchmark as well as the elasticities of substitution $\sigma_{i}^{l}$ and $\sigma_{i}^{s}$ within the utility function can not be observed or estimated directly. However, these parameters can be inferred from empirical estimates of the uncompensated elasticity of savings with respect to the interest rate, $\psi$, the uncompensated elasticity of labour supply with respect to the 
net wage, $\xi_{w}$, and with respect to total income, $\xi_{I}$. Using the demand equations of Section 2.2, the following relationship between the uncompensated savings elasticity and the elasticity of substitution between current consumption and savings applies (see Rutherford 1995, index $i$ has been dropped):

$$
\psi=\sigma^{s} \theta^{H}+\frac{r K}{I_{e}} .
$$

We set the elasticity of savings with respect to the interest rate equal to 0.4 (see Bernheim 2001).

The relationship between the uncompensated labour supply elasticity and the elasticity of substitution between leisure and consumption is more involved. In our concrete model, labour supply is a complex function of not only $r V_{U}$, the price of leisure, but also all the $w_{s}$ and $b$. Moreover, these variables are not independent of one another, but linked through equilibrium constraints. We assume that all $\tilde{w}_{s}, b$ and $r V_{U}$ change by the same amount and match the household's reaction on this change with the empirical labour supply elasticity. In line with Rutherford (1995), we use the following expression:

$$
\begin{aligned}
\xi_{w}=-\frac{d l}{d\left(r V_{U}\right)} \frac{r V_{U}}{L S}=-\left(\frac{\partial l}{\partial\left(r V_{U}\right)}+\frac{\partial l}{\partial I_{e}}\right. & \left(\frac{\partial I_{e}}{\partial\left(r V_{U}\right)}+\sum_{s} \frac{\partial I_{e}}{\partial \tilde{w}_{s}}+\frac{\partial I_{e}}{\partial b}\right) \\
& \left.+\frac{\partial l}{\partial p_{H}} \frac{\partial p_{H}}{\partial\left(r V_{U}\right)}+\frac{\partial l}{\partial p_{U}} \frac{\partial p_{U}}{\partial\left(r V_{U}\right)}\right) \frac{r V_{U}}{L_{S}} .
\end{aligned}
$$

This can be simplified to

$$
\xi_{w}=\frac{l}{L_{S}}\left(\sigma^{l}-\left(\sigma^{s}-\sigma^{l}\right) \theta^{l} \frac{V_{U}}{\bar{V}_{U}} \frac{\bar{p}_{H}}{p_{H}}-\left(\sigma^{s}-1\right) \theta^{H} \theta^{l} \frac{V_{U}}{\bar{V}_{U}} \frac{\bar{p}_{U}}{p_{U}}-\frac{r V_{U} \bar{L}}{I_{e}}\right) .
$$

Using the benchmark values and solving for $\sigma^{l}$, we obtain

$$
\sigma^{l}=\frac{\bar{\xi}_{w} /(\zeta-1)-\sigma^{s} \theta^{l}\left(1-\theta^{H}\right)-\theta^{H} \theta^{l}+\theta^{L}}{1-\theta^{l}}
$$

where

$$
\theta^{L}=r \bar{V}_{U} \bar{L} / I_{e}
$$


Furthermore, the total income elasticity is given as

$$
\xi_{I}=\frac{1-\zeta}{\zeta} \frac{r V_{U} \bar{L}}{I_{e}}
$$

We first determine $\zeta$ by (53) and then $\sigma^{l}$ by (52) (see Ballard, 2000). By default, the uncompensated wage elasticity and the total income elasticity of labour supply are set at 0.15 and -0.19 , respectively, which reflects empirical evidence (see e.g. Borjas, 2000, p. 47).

\section{II.3.4 Calibration of $\rho_{i}$}

For each sector, we take the two FOC of the Nash bargain, evaluate them at the benchmark, and numerically solve for the $\rho_{i}$ so that benchmark unemployment is met.

\section{II.3.5 Unemployment and separation rates}

The overall unemployment rate is taken from official statistics of the Federal Employment Office (Arbeitsamt). The rate for the unskilled workers is based on own calculations using the German Microcensus (Mikrozensus). Separation rates are computed from the IAB-Employee sample (IABS), which is a one per cent sample of the complete employment register data. They are defined as outflows into unemployment within one year over the number of employees in the middle of the same year. For the numerical simulations, we take a 5-year average (1991-1995).

\section{II.3.6 Income tax rates and replacement ratio}

The main sources for income taxes are the tax revenue statistics of the Federal Ministry of Finance (BMF, 2000). In order to decompose overall tax revenues into contributions of different agents and sectors, the following approach has been used:

- Labour income tax: We assume that both representative worker households consist of a married couple with one bread-winner and one child. Both the 
average and the marginal wage tax of such a household (at the average income per skill type) are reported in official tax tables (Bundesminister der Finanzen 1992). We employ the ratio between average tax rates for low-skilled and highskilled workers and the coefficient of residual income progression (CRIP). The actual tax rates used in the model are then calculated such that the officially reported tax revenue is reproduced. Marginal rates are adjusted so as to keep the CRIP for both types.

- Capital income tax: We model a dual income tax, which treats incomes from different sources differently. To determine the average tax burden on capital, we sum up the revenue of the interest tax and the non-assessed income tax and add a small part of the assessed income tax according to information given by federal authorities (BMF, 2000, p. 32).

- Tax on profits: All other taxes levied on companies are treated as a profit tax. They include the corporate tax and parts of personal income taxation.

As to the replacement ratio, we follow the specification of the unemployment insurance system, which amounts to $67 \%$ of the last net earnings for a married person with one child. In our model simulations, we have fixed the unemployment benefits relative to the net wage.

\section{II.3.7 Wage differentials}

Wage differentials are estimated using data from the German Socio-Economic Panel (SOEP Group 2001). We pool observations from five waves in the 1990s and estimate wage equations, including industry dummies. Table 8 reports on the estimated wage differentials. Wages in the lowest wage sector are normalised to one.

Other approaches that are based on more comprehensive data apply panel estimators to determine inter-industry wage differentials (Haisken-DeNew and Schmidt 1999) or are even able to exploit matched data sets that include information on the employer as well as the employee (see e.g. Abowd et al. 1999). Both ways tend to reduce the estimates, since they can take additional heterogeneity into account. 


\begin{tabular}{|c|c|c|}
\hline \multirow[t]{2}{*}{ Industry } & \multicolumn{2}{|c|}{ "Wage (relative to lowest) } \\
\hline & skilled & unskilled \\
\hline Agriculture & 1.000 & 1.000 \\
\hline Energy \& Mining & 1.288 & 1.279 \\
\hline Manufacturing & 1.212 & 1.201 \\
\hline Construction & 1.226 & 1.226 \\
\hline Trade \& Transport & 1.077 & 1.062 \\
\hline Banking & 1.215 & 1.204 \\
\hline Other Services & 1.040 & 1.022 \\
\hline
\end{tabular}

Table 8: Wage Differentials

The latter approach (matched employer-employee data) even eliminates almost all differentials.

The empirical estimates of German wage differentials are too large to be used in their raw form in the arbitrage calculus of the unemployed workers. We observe small sectors with very low wages (hotel industry, private services), which means that a large part of the economy must have high unemployment to make the unemployed indifferent between all sectors. The arbitrage condition cannot be balanced in this way by the actual unemployment rates for Germany. We therefore include a nonpecuniary wage component for employment in each sector in the value equation for $V_{s, t}$. (see 2.3.2) The sector-specific nonpecuniary wage component can be conceived of as hypothetical payments that make low wage sectors more attractive than solely reflected in their wage. To maintain homogeneity, the nonpecuniary wage components $\delta_{s}$ are expressed as a fixed fraction of the wage, i.e. $\tilde{w}_{s}$ becomes $\tilde{w}_{s}\left(1+\delta_{s}\right)$. Thus, we have a dual account for sectoral wage differences. They are partly attributed to non-pecuniary differences between the sectors (which reflects the empirical long-term stability of wage differentials) and partly to differences in labour market tightness. 


\section{II.3.8 Others}

Armington elasticities are taken from Welsch (2001). They range between 0 and 2 . Services and the construction sector are treated as non-tradables.

The elasticity of transformation between domestically supplied and exported goods is uniformly set to 2 .

The depreciation rate of the capital stock (in our case: $4.76 \%$ ) is derived using information from the Federal Statistical Office on the net value of capital and depreciation in 1995.

Savings equal total investment, which is the sum of all expenditures on investment good in the benchmark period. To split up total savings between the two representative households, information from continuous household budget surveys is employed (Statistisches Bundesamt 1995). 


\section{CESifo Working Paper Series}

(for full list see www.cesifo.de)

1209 Stephan Klasen and Thorsten Nestmann, Population, Population Density, and Technological Change, June 2004

1210 Wolfgang Ochel, Welfare Time Limits in the United States - Experiences with a New Welfare-to-Work Approach, June 2004

1211 Luis H. R. Alvarez and Erkki Koskela, Taxation and Rotation Age under Stochastic Forest Stand Value, June 2004

1212 Bernard M. S. van Praag, The Connexion Between Old and New Approaches to Financial Satisfaction, June 2004

1213 Hendrik Hakenes and Martin Peitz, Selling Reputation When Going out of Business, June 2004

1214 Heikki Oksanen, Public Pensions in the National Accounts and Public Finance Targets, June 2004

1215 Ernst Fehr, Alexander Klein, and Klaus M. Schmidt, Contracts, Fairness, and Incentives, June 2004

1216 Amihai Glazer, Vesa Kanniainen, and Panu Poutvaara, Initial Luck, Status-Seeking and Snowballs Lead to Corporate Success and Failure, June 2004

1217 Bum J. Kim and Harris Schlesinger, Adverse Selection in an Insurance Market with Government-Guaranteed Subsistence Levels, June 2004

1218 Armin Falk, Charitable Giving as a Gift Exchange - Evidence from a Field Experiment, June 2004

1219 Rainer Niemann, Asymmetric Taxation and Cross-Border Investment Decisions, June 2004

1220 Christian Holzner, Volker Meier, and Martin Werding, Time Limits on Welfare Use under Involuntary Unemployment, June 2004

1221 Michiel Evers, Ruud A. de Mooij, and Herman R. J. Vollebergh, Tax Competition under Minimum Rates: The Case of European Diesel Excises, June 2004

1222 S. Brock Blomberg and Gregory D. Hess, How Much Does Violence Tax Trade?, June 2004

1223 Josse Delfgaauw and Robert Dur, Incentives and Workers' Motivation in the Public Sector, June 2004 
1224 Paul De Grauwe and Cláudia Costa Storti, The Effects of Monetary Policy: A MetaAnalysis, June 2004

1225 Volker Grossmann, How to Promote R\&D-based Growth? Public Education Expenditure on Scientists and Engineers versus R\&D Subsidies, June 2004

1226 Bart Cockx and Jean Ries, The Exhaustion of Unemployment Benefits in Belgium. Does it Enhance the Probability of Employment?, June 2004

1227 Bertil Holmlund, Sickness Absence and Search Unemployment, June 2004

1228 Klaas J. Beniers and Robert Dur, Politicians' Motivation, Political Culture, and Electoral Competition, June 2004

1229 M. Hashem Pesaran, General Diagnostic Tests for Cross Section Dependence in Panels, July 2004

1230 Wladimir Raymond, Pierre Mohnen, Franz Palm, and Sybrand Schim van der Loeff, An Empirically-Based Taxonomy of Dutch Manufacturing: Innovation Policy Implications, July 2004

1231 Stefan Homburg, A New Approach to Optimal Commodity Taxation, July 2004

1232 Lorenzo Cappellari and Stephen P. Jenkins, Modelling Low Pay Transition Probabilities, Accounting for Panel Attrition, Non-Response, and Initial Conditions, July 2004

1233 Cheng Hsiao and M. Hashem Pesaran, Random Coefficient Panel Data Models, July 2004

1234 Frederick van der Ploeg, The Welfare State, Redistribution and the Economy, Reciprocal Altruism, Consumer Rivalry and Second Best, July 2004

1235 Thomas Fuchs and Ludger Woessmann, What Accounts for International Differences in Student Performance? A Re-Examination Using PISA Data, July 2004

1236 Pascalis Raimondos-Møller and Alan D. Woodland, Measuring Tax Efficiency: A Tax Optimality Index, July 2004

1237 M. Hashem Pesaran, Davide Pettenuzzo, and Allan Timmermann, Forecasting Time Series Subject to Multiple Structural Breaks, July 2004

1238 Panu Poutvaara and Andreas Wagener, The Invisible Hand Plays Dice: Eventualities in Religious Markets, July 2004

1239 Eckhard Janeba, Moral Federalism, July 2004

1240 Robert S. Chirinko, Steven M. Fazzari, and Andrew P. Meyer, That Elusive Elasticity: A Long-Panel Approach to Estimating the Capital-Labor Substitution Elasticity, July 2004 
1241 Hans Jarle Kind, Karen Helene Midelfart, Guttorm Schjelderup, Corporate Tax Systems, Multinational Enterprises, and Economic Integration, July 2004

1242 Vankatesh Bala and Ngo Van Long, International Trade and Cultural Diversity: A Model of Preference Selection, July 2004

1243 Wolfgang Eggert and Alfons J. Weichenrieder, On the Economics of Bottle Deposits, July 2004

1244 Sören Blomquist and Vidar Christiansen, Taxation and Heterogeneous Preferences, July 2004

1245 Rafael Lalive and Alois Stutzer, Approval of Equal Rights and Gender Differences in Well-Being, July 2004

1246 Paolo M. Panteghini, Wide vs. Narrow Tax Bases under Optimal Investment Timing, July 2004

1247 Marika Karanassou, Hector Sala, and Dennis J. Snower, Unemployment in the European Union: Institutions, Prices, and Growth, July 2004

1248 Engin Dalgic and Ngo Van Long, Corrupt Local Government as Resource Farmers: The Helping Hand and the Grabbing Hand, July 2004

1249 Francesco Giavazzi and Guido Tabellini, Economic and Political Liberalizations, July 2004

1250 Yin-Wong Cheung and Jude Yuen, An Output Perspective on a Northeast Asia Currency Union, August 2004

1251 Ralf Elsas, Frank Heinemann, and Marcel Tyrell, Multiple but Asymmetric Bank Financing: The Case of Relationship Lending, August 2004

1252 Steinar Holden, Wage Formation under Low Inflation, August 2004

1253 Ngo Van Long and Gerhard Sorger, Insecure Property Rights and Growth: The Roles of Appropriation Costs, Wealth Effects, and Heterogeneity, August 2004

1254 Klaus Wälde and Pia Weiß, International Competition, Slim Firms and Wage Inequality, August 2004

1255 Jeremy S. S. Edwards and Alfons J. Weichenrieder, How Weak is the Weakest-Link Principle? On the Measurement of Firm Owners’ Control Rights, August 2004

1256 Guido Tabellini, The Role of the State in Economic Development, August 2004

1257 François Larmande and Jean-Pierre Ponssard, EVA and the Controllability-congruence Trade-off: An Empirical Investigation, August 2004 
1258 Vesa Kanniainen and Jenni Pääkkönen, Anonymous Money, Moral Sentiments and Welfare, August 2004

1259 Panu Poutvaara and Andreas Wagener, Why is the Public Sector More Labor-Intensive? A Distortionary Tax Argument, August 2004

1260 Lars P. Feld and Stefan Voigt, Making Judges Independent - Some Proposals Regarding the Judiciary, August 2004

1261 Joop Hartog, Hans van Ophem, and Simona Maria Bajdechi, How Risky is Investment in Human Capital?, August 2004

1262 Thomas Eichner and Rüdiger Pethig, Efficient Nonanthropocentric Nature Protection, August 2004

1263 David-Jan Jansen and Jakob de Haan, Look Who's Talking: ECB Communication during the First Years of EMU, August 2004

1264 David F. Bradford, The X Tax in the World Economy, August 2004

1265 Hans-Werner Sinn, Migration, Social Standards and Replacement Incomes. How to Protect Low-income Workers in the Industrialized Countries against the Forces of Globalization and Market Integration, August 2004

1266 Wolfgang Leininger, Fending off one Means Fending off all: Evolutionary Stability in Submodular Games, August 2004

1267 Antoine Bommier and Bertrand Villeneuve, Risk Aversion and the Value of Risk to Life, September 2004

1268 Harrie A. A. Verbon and Lex Meijdam, Too Many Migrants, Too Few Services: A Model of Decision-making on Immigration and Integration with Cultural Distance, September 2004

1269 Thomas Eichner and Rüdiger Pethig, Economic Land Use, Ecosystem Services and Microfounded Species Dynamics, September 2004

1270 Federico Revelli, Performance Rating and Yardstick Competition in Social Service Provision, September 2004

1271 Gerhard O. Orosel and Klaus G. Zauner, Vertical Product Differentiation When Quality is Unobservable to Buyers, September 2004

1272 Christoph Böhringer, Stefan Boeters, and Michael Feil, Taxation and Unemployment: An Applied General Equilibrium Approach, September 2004 